\title{
Out of Egypt and Into the Blackness: African American Professorial Notes on a Graduate Seminar in the Anthropology of Consciousness
}

By

\author{
Enoch H. Page \\ $2004 \odot$ \\ Department of Anthropology \\ 204 Machmer Hall \\ University of Massachusetts \\ Amherst, Massachusetts 01003 \\ 413.546.4598 \\ hepage@anthro.umass.edu
}




\section{Introduction}

A growing corpus of disparate anecdotal evidence suggests that a state of supra-mundane consciousness was once accessible to many more humans. Some who have known this state describe it as an existential condition of boundless awareness, one that may be achieved by any embodied person. Following Varela, Thompson and Rosch (1991), we can conceptualize this lost potential as our alleged or forgotten human capacity to develop an unexpected degree of knowledge of how to manipulate our attention by turning it inward.

To explore what experience is available to us through deep meditation, a willingness and determination to practice intently is required. These are two pre-conditions that make it possible for us to know or cognize what some of us have identified as an inner Self. When referring to this conception of "Self," we are not speaking in terms of the small 's' form of the familiar social self, person or personality; nor do we speak of a performance, nor do we speak of an imagined self known to one in dreams, as studied by Iain Edgar (1999). Rather we speak of an embodied Self. To explain what we mean by "the Self" or when speaking of "Self knowledge" let me say that I use these terms in the tradition of meditation masters and teachers who postulate the Self as pure consciousness, not in the Husserlian sense, but in the sense of an apparently fragmented aspect of cosmic consciousness with each apparent fragment being embodied in living things. My usage of Self is grounded in a process of autopoeisis defined by Varela and Maturana that conceptually is closer to Merleau-Ponty's Phenomenology of Perception. So, any reference to the "Self" is used in this essay as a metaphor referring to that fragment of universal consciousness that constitutes its manifest being as our personal and collective embodiment in a world that it also constitutes.

Perhaps we can better understand how culturally specific metaphorical language describes this universally accessible human experience if we consider the position of Haskell, Linds and Ippolito (2002, September), who provide the following insight from their new social science methodology based on their knowledge of eastern thought:

If in fact we are trying to get at the phenomena of experience, we must first realize that the interaction with phenomena is an embodied cognition. This embodiment is the essence of being that may be expressed through perception or conception. The conceptions of abstract and metaphoric thinking allow us to engage and bring forth the theories of our time. Theorizing is then an embodied experience which is not separate from our experiencing.

Lakoff and J ohnson (1999) consider how the coherent consciousness of Self ${ }^{1}$ knowledge may be associated with supra-human powers that seem fantastical given our current era of dissipated and refracted human consciousness. Such powers were popularized in the film, Crouching Tiger, Hidden Dragon which comically depicts the enactment of mythical human potentials for modern audiences with whom super-heros are popular again. What may be taken for granted is the films' allegory about the unusual things that people can do who have acquired a certain kind of wisdom that once was propagated throughout the old world by the initiates of an ancient tradition. While many may desire these powers, today we assume that they either don't exist or were purposely put beyond the reach of the uninitiated. Extraordinary human ability therefore has remained the claim of advanced adepts and has been relegated to dubious categories, because science generally has been unable to document their claims using normal methods of investigation. Consequently, such claims lack scientific validity.

\section{Meditative Performance, Anxiety and The Sedative Super-hero}

It is widely presumed that supra-human abilities are purely fictitious, and yet such claims persist. Claimants try to prove their feats by presenting themselves to be tested. For example, in December of 2003 an unknown yogi astounded doctors in India when they put him under strict medical observation for two weeks to test his claim that he had neither eaten, drank, nor expelled any waste for decades. Doctors and the media assumed the bright-eyed, scrawny, but vigorous old man either had to be lying or delusional. Surely he was so thin that he would demand food in a few days, they presumed, but much to their amazement, he remained secluded in antiseptic hospital conditions for two weeks, lost no weight, and passed all of their medical tests without ingesting any food or water molecules. This non-eating yogi and others, like Sri

${ }^{1}$ When we speak of "Self knowledge" or "the Self" in this essay I use the term to postulate pure consciousness, not in the Husserlian sense. My sense of this term is grounded in an a process of autopoeisis that is far closer to Merleau-Ponty's Phenomenology of Perception. So, any reference to "Self" is a metaphor referring the fragment of universal consciousness that constitutes our personal and collective embodiment in the world. When using the term "Self," we are not speaking of the small 's' self of the person or personality nor do we speak of the imagined self known to one in dreams, as studied by Iain Edgar (1999). 
Chinmoy, perform mind-boggling feats that challenge our commonsense assumptions that human needs and limits must be observed in order to survive. Most humans share this restricted conception of the mundane life, but deep meditators sometimes dissolve these limits.

Bourguignon notes a growing concern that our society may be suffering from ecstasy-deprivation. If so, then the malady may be symptomatic of our increasingly outward (centripetal) attention. Failing to recognize that we may need to reorganize more of our attention centrifugally, we continue producing studies that select from among what is familiar and within the bounds of what we regard as tenable. The aim of efficacious meditation is to expand one's sense of self-awareness beyond spacetime parameters of the known into a realm of the Self that is said to be non-dual. My seminar, the Anthropology of Consciousness examines this concept of supra-mundane states and abilities. I do not teach meditation; I encourage students to consider what limitations we recognize and ask them to imagine what it might be like no longer to recognize some of those limits. I tell them that this was the same lesson taught by initiates in an ancient tradition.

\section{A Seminar on the Self}

I discuss seminar details in my manuscript, Out of Egypt and into the Blackness: Embracing All Children of Light. Generally, the course is designed to alert students to our shared predicament and our grand opportunity. We set out to correct the imbalance by learning to value the centripetal attention required for efficacious meditation. I believe this is a preferable response to Ehrenreich's call for an ecstasy machine (Bourguignon 2003:5). The seminar makes pedagogical intervention into the modernity that in only two thousands years has swept aside the ancient tradition and with it we lost knowledge of our true human potential. The course reminds students of what the ancients taught and warns them that they cannot grasp the information if they are unwilling to enter the blackness. This blackness for them is inward, and it's a history of embodied blackness that has been expunged in the global interest of western racial domination.

Following the ancient tradition the seminar makes three basic assumptions:

1) embodiment is an enactment of consciousness

2) the Self is not a body or a being but a knowing unity to be known

3) coming to know the Self requires the inward relational motion of identity

These ideas once sounded like those that fell from the mouths of mumbo-jumbo of charlatans who led people astray by offering fake meditation instructions would lead them no where. Today the same ideas are the findings of modern science as Damasio (Rich 2002) and others are discovering.

Through a process of autopoeisis all living things distinguish themselves from their background and according to the ancient tradition, the actual background is not the apparent environment, but rather is the consciousness that is the Self, the witness of which we may become aware. The ancients taught that the Self is universally one. This suggests that we technically are one inseparable unity, not apparently or metaphorically one as indicated by much of contemporary rhetoric. Quantum physics proves this oneness, but we have not done enough to make this fact common knowledge. Damasio and others have found that the body with which we identify can be apprehended as an object and as subjectivity known as the self with a small s. But deep within he explains there is something else going on by means of which another level of identity is known and knowable, but not consciously so.

In other words, it now may be possible to understand deep meditation through some kind of an enactive approach to the study of consciousness based on "the growing conviction that cognition is not the representation of a pre-given world by a pre-given mind but is rather the enactment of a world and a mind on the basis of history of the variety of actions that a being in the world performs" (Varela, et al., 1991:9). The great meditators state that it is possible to meditate long and well enough so that one witnesses the Self although we must pass through several levels of bodily identification in sequence and detach from each previous level in a way that makes apprehension of the next level possible. Hence it is possible to experience deeper and deeper meditation. By persisting without distraction one eventually can experience reality as if one were a disembodied witness called Self. But more important, ancient meditators state unequivocally that spending time in this state changes us so profoundly that we can develop new goodness and powers when we once again are aware of the body or we permanently can pass out of the body with full awareness. In other words, there is the suggestion that we are not the body and that the body really is some kind of a vibratory vehicle, at best, and a light-sink, at worst.

\section{Building Light Bodies}

As a vehicle of consciousness the body enables us to have a material experience, but as a light-sink, our bodies and all living things in DNA, in the pineal and in melanin-rich interior nervous tissue store a tremendous amount of light that has bio-photonic potential. ${ }^{2}$ Such findings suggest that the ancients may

${ }^{2}$ Bridges (2003) draws our attention to recent scientific discoveries where it has been found that DNA emits a weak form of coherent light. This finding corresponds with my own investigation into melanin in which I 
not have been wrong in their claims that it was possible to build light bodies. ${ }^{3}$ In our seminar we examine how this message has been suppressed, beginning with the rise of the Roman Church. Operating in competition with the ancient tradition, the Church found it necessary not only to persecute the original practitioners of this light body tradition, ${ }^{4}$ but they also continued this persecution for at about 800 years before they posed no further threat. As a result, the tradition went underground, as it were. Having had revolutionary roots just two thousand years ago, today it is once again trying to come out of the closet although the tradition existed up to five thousand years ago in China, Egypt and India.

I argue that it traveled north from Egypt starting around $1500 \mathrm{BC}$ although most European descent researchers locate the date of transmission around the $1^{\text {st }}$ century. This dating is unmerited and it seem distorts the antiquity of the Egyptian geneology. But the evidence is indicates that the ancient tradition came to be coded in what is known as the language of the birds, ${ }^{5}$ a metaphorical way of hiding sacred knowledge not only from the uninitiated but mainly from the hostile governments who would love either to have its powers or if not, then to eradicate anyone else who might have them.

Ancient Theory

The seminar is mainly built of web sites, but there is one text, The Yoga Vasistha (Venkatesananda 1993). The book is written in the language of the birds that existed throughout the old world and not just in India but it always had been translated into the local vernaculars. The usual approach is to treat this book as a cultural document to be interrogated from a rational, analytical point of view. The teacher is the only recognized knower and the text is open to be known. In contrast, seminar students must treat this corpus of vedic treatises as theory, not as a religious text full of exotic beliefs that need to analyzed from the viewpoint of western rationality, but rather they are asked to treat the wisdom offered by the Yoga Vasistha not as spiritual theology, but as a different and equally valid ontological theory.

By learning to read this metaphorical language as theory, the students open themselves to the wisdom of this book and feel it operating on the boundaries of their awareness as they shift from a quaint response to an incredulous one to finally a response more like awe. Their closed minds open to another conception of the world that I argue is just as valid as our own scientific one. We discuss whether or not it may be possible to enforce the ontological view of the Yoga Vasistha as the scientific one is enforced. Students realize how this book takes them deeper into the realization that inward consciousness is malleable. They identify some of the struggles with their own path as meditators. Like Rama, they see similarity in their own detachment from the world and can relate to his dispassion. Today, Rama would be given Prosac and a potential meditator would be lost. Although the language, range and approach of the Yoga Vasistha seems strange to my students at first, they quickly come see it is not offering them a religion. They then drop their suspicions and love the insight it contains. Each of them see that the wisdom contained in this book does not differ much in theory from the knowledge put forward by Swami Muktananda ${ }^{6}$ or Paramahansa Yogananda, two

found scholars who also have proven that under certain circumstances, melanin also emits light. So, the green language has something to do with the role of light in the human body. Until humankind was scientifically and socially evolved enough to entertain this idea, the information had to be hidden because the rise of the Romish Church sought to expunge anyone who had this information.

"Hence Pinoline actually can make the super-conductive elements within our body, the mono-atmonic minerals, useful to our biology, by acting as a biological door, or bio-crystal bridge, which can momentarily superconduct, and transmit that high spin state that it anticipates, into biological availability, as $8 \mathrm{~Hz}$, and bio-photons of life" (Rimon, et. al. 1984).

"The Followers of RA, like the Henmemet, who visited Heliopolis in the early dynastic era, were real people, not spirits. It is from them that the concept of "God the Principle," the "RA Function" passed to the priests of the City of the Sun. The "Light Beings," that is, creatures that are fed on, clothed by, and enveloped in light, naturally became the focus of the religious concept they taught. If we believe (as did the early Egyptians) in the RA Function, the "One God who is All Gods," then we will become like these light beings, the henmemet, when we die, and like them, we will voyage forever in the Boat of a Million Years..."(See, Vincent Bridges, Raising of the Djed.

${ }^{3}$ As in the Pyramid Texts.

${ }^{4}$ See the Book of Adam and Eve, in the Apochrypha.

${ }^{5}$ Also called the green language, cant, argot and related to the art of light. See very important article, by Bridges (2003).

${ }^{6}$ There is a relational movement of our attention away from the subtle body that we encounter first as we move deeper into an awareness of the causal body, and then we shift our attention from what we come to know as the causal body in which one encounters the void and move inward farther still towards an 
gurus whose teachings we discuss in class.

Each of the three perspectives, taken together, establish the proposition that culturally specific knowledge of correct meditation may vary across cultures, but certain cultural conceptions of correct meditation lay claim to what constitutes a correct meditation outcome. In the seminar, we agree that across differing eastern meditation modes, efficacious meditation practice is said to produce highly similar meditation outcomes. The Yoga Vasistha, Paramahansa Yogananda and Swami Muktananda each hail from different ethnic or temporal backgrounds, but they each offer the same basic knowledge of a highly similar, if not identical, meditation outcome.

Uniformity of Practice: Diversity of Terms

When gurus and the Yoga Vasistha use different linguistic terminology for different stages of meditation or describe the outcome of meditation in different terms, we western scholars normally treat these apparently disparate meditation traditions as three different ones. We distinguish Zen meditation from Vipassana meditation or we distinguish Insight Meditation from Trancendental Meditation. We normally are so insistent on how types or styles of meditation differ that we usually can't see them as particular cultural versions of a highly specific ancient tradition. Rather than get bogged down in what's different, in our seminar we examine what's the same across them. What is it that all of these meditation traditions have in common? We assume that wherever efficacious meditation instruction historically has been found, that concepts about what meditation is, or how it correctly must be done, tend to be trans-cultural universal ideas although they metaphorically may be represented in different localities in culturally specific terms.

The ancient claim that mankind is of incorporeal nature is what one is said to discover if one perseveres with efficacious meditation, but when Paramahansa Yogananda made this claim in 1946, we didn't give credence to what he states, after all, he's just a Yogi and not a physicist. We cannot imagine how a Yogi would learn from meditation what we believed that a physicist one day could prove. And now, we have some physics books admitting that matter as immaterial because there is no such thing as a particle of any kind. Yet we are unable to admit that our bodies are not what they appear to be. They are energetic forms, our bodies, not material forms. And of course, this is true of all living forms. So, the two questions put before my students in this regard are 1) when will our comprehension of matter as energy catch up with our knowledge; and, 2) do we really want to catch up?

It is highly probable that we do not feel emotionally and spiritually ready to face these facts and grapple more directly with their implications. For to admit that our bodies are immaterial raises questions about the boundary we have drawn between the natural and supernatural. Thus, to complete this seminar, students must discuss and face four fears: 1) of scholarly reprimand, 2) of going over-board, 3) of new and uncharted responsibility, and 4) of the idea that some humans either can return from death or can remain fully conscious through death (Newberg and d'Aquili 1994). These are topics seminar students explore.

\section{Striking a Gnostic Pose}

In the seminar, we address this fear by assuming a Gnostic pose of the ancient tradition. It taught that embodiment is hell and disembodiment is liberation from hell. Without any cynicism we inquire into this proposition by examining Gnostic philosophy and our journey teaches us two things: the ancients felt spiritual but were not religious, and their ideas that seem religious actually were metaphorical terms for describing cosmological relations. They believed all humans collectively were the Son of God. The Son of God was not a single man, nor any man, but all humanity on this planet, and on any planet, although they did not speak in extraterrestrial terms. We know they held this view this from sacred geometry and we know of the history of Isis. Sacred geometry taught unity is the eternal Self; that unity sought to know itself produced Wisdom, Isis, Sophia, the female counter-energy; and that Wisdom, as sibling-wife and mother,

awareness of the supracausal state in which one increasingly begins to sense one's Self as the disembodied witness of what he calls, "The scintillating point of blue light known as the Blue Pearl." Swami Muktananda goes on to say that one who persists eventually will see the blue light expand into whatever shape is the form of one's conception of God, producing scenes of nature if one is a naturalist, or perhaps, holy personages whose images resonate with the meditator's relationship to mythic characters such as Krishna, Buddha or J esus who may even have been historical characters. In the next phase of meditation, that sacred form is reduced back into a point of blue light, and later in one's practice, after one's contact with the Blue Pearl has stabilized over time, it "will expand infinitely, and its light will fill the universe." And this is the moment of Self knowledge that meditators seek (1981:119): "...you will see that the whole world is shimmering and scintillating with this blue light. You will realize that you yourself are that light, and our feeling of smallness will vanish. Your sense of limitation will melt away, and you will realize your own vastness and your own glory." Having attained this depth of meditative inquiry, to speak metaphorically about one's meditative state, one enters into what Swami Muktananda knows as the state of "natural Samadhi," that he also calls "the highest level of perfection." But let us understand that attaining this state of perfection must be a consequence of a particular form of "enactive inquiry" as prescribed by the ancient tradition that is the focus of this seminar. 
gave birth to a son who was a just man and Christ. ${ }^{7}$ What the tradition held that all things are created through the Christ, that the substance of the mother and father incarnate into form and then into what appears to be matter. Since matter is the flesh of the mother this allows the embodied consciousness to incarnate and experience life, so the definition of gnosis means to know from centrifugal experience all there is to be known. The knower seeks not to explore the universe, but knows from within and goes inward towards liberation.

What is curious is how this tradition could be found not only in Egypt but also in China and India. And even in Judea where it got mixed up with extraneous ideas, there were those revolutionary, dissident non-conformists who knew as did the Egyptians, the Chinese and Indians that despite how it looks, living matter was light and that molecules and atoms can emit light. Through meditation they knew we are light bodies and they called themselves different names, including sons of light.

\section{Whitening Egypt: Expunging Blackness}

What is amazing is that we lost sight of how this call to dwell in the inner blackness in order to locate and experience Self ${ }^{8}$ came from people who had been part of a regional black culture that extended from Egypt up into India. According to Martin Bernal's Black Athena, British scholars knew prior to 1850 that more than once Egypt had been black, and even earlier they knew that much of the old world had been black. For instance, consult the Anacalysis by Godfrey Higgins who in 1833 builds a strong case that depictions of Buddha and J esus had been black with quite negroid features while the depicted features of black Krishna were more recent and more aquiline.

Students are amazed but are not surprised to learn from Bernal and Young that certain western scholars erased from the historical record most knowledge of this black ancient tradition. They did so to erect white supremacy on a scientific basis and thereby finished what the church of Rome began: the whitening of the ancient tradition and the loss of the correct meditation methods that can make men and women free.

Noting how the whitening of Egypt became a defense of the polygenticist position, Young (1995:) indicates that American and British scholars like Gliddon and Nott conspired in both monument and craniological studies to prove that Blacks merely had been the slaves of ancient white Egyptians, and thus, had played no significant role in Egypt's dynastic civilizations. According to this theory, Egypt may have been a nameless land occupied by Blacks who did nothing with it until whites either originated there themselves or later arrived there from elsewhere to civilize that fertile land.

Organizing proof for this claim between 1830 and 1840 was intended to counter fellow white scholars who already had sufficient evidence that Blacks, in fact, had been the rulers of Egypt more than once, and even had excelled in other lands. Martin Bernal was reprimanded for arguing that European scholars knew quite well that ancient Egyptian blacks had colonized and civilized the archaic Aegean societies that gave rise to ancient Greece. Yet, the need of racist white scholars to deny their former knowledge of Egypt's blackness and make that nation white was so strong and compelling, as Young (1995: 128) reports, that in 1841 Gliddon wrote to S. G. Morton, "I am hostile to the opinion of the African origin of the Egyptians."

Young explains that the polygeneticists could not accept a Black Egypt. If that known fact remained true, he argues (1995:127-28) it would constantly be called upon to undermine their insistence on the natural inferiority of Blacks and it also would cause themselves to confess that Blacks had created the first cilivilization and first knowledge. In support of this argument, John Stuart Mill confronted Carlyle with evidence that the earliest known civilization had been black and that the Greeks, as Bernal later, tried to prove, had been civilized by Egyptian Blacks. Backing up Mills argument at a later date, St. Clair Drake (1987) found the most clear evidence that Blacks held prominence in three several Egyptian dynasties:

Old Kingdom: 2750 B.C to 2200 B.C. [3 $3^{\text {rd }}$ and $4^{\text {th }}$ dynasties]

New Kingdom: 1550 B.C. to 1305 B.C. [18 ${ }^{\text {th }}$ dynasty, Akhenaten and Tutankamen]

New Kingdom: 715 B.C. to 656 B.C. [25 ${ }^{\text {th }}$ Ethiopian or Kushitic dynasty]

He (1987:144) also found evidence that "Negroid pharaohs, priests, and intellectuals were prevalent."9 Rather than accept Mills' evidence of Black Egyptian leadership, Nott declared that Aryans from India had been the original and permanent leaders of dynastic Egypt (Young 1995: 130) and Godfrey Higgins joined in this travesty. While racist arguments designed to whiten Egypt sought to discount black humanity and

\footnotetext{
${ }^{7}$ Similarly, we can see the same tradition as in Egypt, as Godfrey Higgins notes, for "Buddha, the son of Máyá, is considered as the God of J ustice."

${ }^{8}$ In the case of Frederick Douglas, see how scientific racism in anthropology damages the black sense of self by making self-talk no different from racist talk about race (Chaney 2001).

${ }^{9}$ See article by Cheik Anta Diop on the UNESCO World Congress in which he uses physics to test their melanin content and demonstrate that Pharoahs were black.
} 
rationalize black enslavement, St. Clair Drake (1987:259) concedes that later Hellenicization terminated the prominence of cultural and phenotypical blackness due to a pervasive adoption of Romish cultural practices $^{10}$ that served to whiten the value that Ethiopian and Egyptian people formerly placed on dark skin color. A similar argument was made by Chancellor Williams in his important study, The Destruction of Black Civilization

\section{References}

Bridges, Vincent. (2003). Reading the Green Language of Light. J ournal of the Western Mystery Tradition. 4(1) Vernal Equinox.

Bourguignon, Erika. (2003). Faith, Healing, and "Ecstasy Deprivation": Secular Society in a New Age of Anxiety. Anthropology of Consciousness. 14(1):1-19.

Chaney, Michael, A. (Fall 2001). Picturing the Mother, Claiming Egypt: My Bondage and My Freedom as Auto(bio)ethnography.(Critical Essay)

African American Review.

http:// www.findarticles.com/cf_dls/m2838/3_35/79758784/p1/article.jhtml?term

Edgar, Iain. (1999). Dream fact and real fiction: the realization of the imagined self. Anthropology of Consciousness. 10(1):28-42.

Haskell, J ohnna, Linds, Warren \& Ippolito, J ohn (2002, September). Opening Spaces of Possibility: The Enactive as a Qualitative Research Approach [96 paragraphs]. Forum Qualitative Sozialforschung / Forum: Qualitative Social Research [On-line J ournal], 3(3). Available at: http:// www.qualitative-research.net/ fqs/ fqs-eng.htm [Date of access: March 12, 2004].

Lakoff, George, and J ohnson, Mark (1999). Philosophy in the flesh: The embodied mind and its challenge to western thought. New York: Basic Books.

Page, Enakh H. (n.d.) Out of Egypt and Into the Blackness: Embracing All Children of Light. Manuscript.

Rich, Grant (2002). Body and Consciousness: A conversation with Antonio Damasio. Anthropology of Consciousness 11(3-4):54-61.

Rimon R; Airaksinen MM; Kari I; Gynther J ; Ven:al:ainen E; Heikkil:a L; Ryypp: oJ ; Palo J A-4629. PINOLINE, A BETA-CARBOLINE DERIVATIVE IN THE SERUM AND CEREBROSPINAL FLUID OF PATIENTS WITH SCHIZOPHRENIA. Ann Clin Res: 16:3: 171-5 (1984)

Swords, Michael D. (1990) Using the Study of Anomalies to Enhance Critical Thinking in the Classroom. J ournal of Scientific Exploration. 4(2).

10 The oneness of Africa with the Old World was violated by 19th European scholars who saw the Roman conquest of Carthage as evidence for their claims of a white or Aryan Egypt. The Hellenizing cultural developments in question are:

...connected with the three Punic Wars which took place in the years 264-242 BC, 218-202 BC, 149-146 BC, between Carthage and Rome.

... The primary military rivals of these campaigns, as generals, were Hannibal on the side of Carthage and Scipio Africanus on the part of Rome. After Hannibal's epic descent onto Italy across the Alps with herds of elephants Carthage was realized as being Rome's most formidable enemy. Hence came Cato the Elder's injunction that "Carthage has to be destroyed." (Delenda est Carthago). The end of the third Punic War in 146 BC saw the total destruction of the city of Carthage. In what is now Tunisia, Rome established a province in North Africa in the fertile region behind the ruined city of Carthage. This came to be known as Roman Africa. 
Varela, Francisco J., Thompson, Evan, and Rosch, Eleanor (1991). The embodied mind: Cognitive science and human experience. Cambridge, MA: MTT Press.

Venkatesananda, Swami, ed. The Yoga Vasistha. (1993). State University of New York Press.

Young, Robert J . C. (1995). Colonial Desire: Hybridity in Theory, Culture and Race. New York: Routledge.

\section{Websites}

Amorphous Semiconductor Switching in Melanins Reprinted with permission from Science, vol 183, 853855 (1974). copyright 1974, American Association for the Advancement of Science.

Science Homepage http:// www.sciencemag.org

La natura del nero degli animali. The Nature of Animal Blacks.

http://www.tightrope.it/nicolaus/metadoc10.htm 